\title{
Pre and Post Effects on Schooling Due to Covid-19
}

\author{
Ruchi Sahu, Jay Kumar Jain
}

\begin{abstract}
This project will show that how activities that done by the school is important for the new learners. This stored all the activities of school that enhance the development of each child towards their career after Covid impact. Involvement in cocurricular Activities helps student become tougher and avoid mental health issues. There is a lack of such activities which will enhance the knowledge of child with Covid precautions and if parents want to develop their child's knowledge in technology and also for online activities, So there is not such platform where they can do all this without misusing the technology in unawareness also if parents wants to polish their interest, so that, they can think to make a career in it. So, how can they analyse that whatever the school will be able to do it or not, without visiting each school due to Covid 19. we will mention the facilities, activities, skills and international activities, events, to do using technology, etc. in the project. This project will have own interface/platform for online activities for students so that they could not misuse the technology. There is some online activities (Activities From Home) in Project that can be done while making some social - distance because of Covid. This project can increase efficiency of skill development and career opportunities from their interest in respective activity or skill. Managing the impact of COVID-19 on education systems without losing required knowledge for students via Incredible school activity as well.
\end{abstract}

\section{INTRODUCTION}

This website is to analyse that how activities that done by the school is important for the new learners. This stored all the activities of school that enhance the development of each child towards their career after Covid impact. Involvement in co-curricular Activities helps student become tougher and avoid mental health issues. As Covid19 lockdown eases, all precautions need to be taken for teacher and student safety.

Earlier this year, mandatory shutdowns shuttered schools and pushed most of the world into emergency remote learning situations. Schools turned to video conferencing tools, online learning management software, and other digital solutions to keep education ongoing.

Surveys suggest nearly half of parents are dissatisfied with how their children have performed academically during the pandemic, while $70 \%$ of teachers feel students haven't adapted well to remote learning.

Manuscript received on 21 June 2021 | Revised Manuscript received on 02 July 2021 | Manuscript Accepted on 15 July 2021 | Manuscript published on 30 July 2021.

* Correspondence Author Application, Sagar Institute of Research and Technology, Bhopal (MP), India Email: sahu2101ruchi@gmail.com

Dr. Jay Kumar Jain, Assoc. Professor and Head, Department of Master of Computer Application, Sagar Institute of Research and Technology, Bhopal (MP), India

(C) The Authors. Published by Lattice Science Publication (LSP). This is an open access article under the CC-BY-NC-ND license (http://creativecommons.org/licenses/by-nc-nd/4.0/)
Keywords: Activities, Covid Impact, School Activities.

Ruchi Sahu*, PG Scholar, Department of Master of Computer

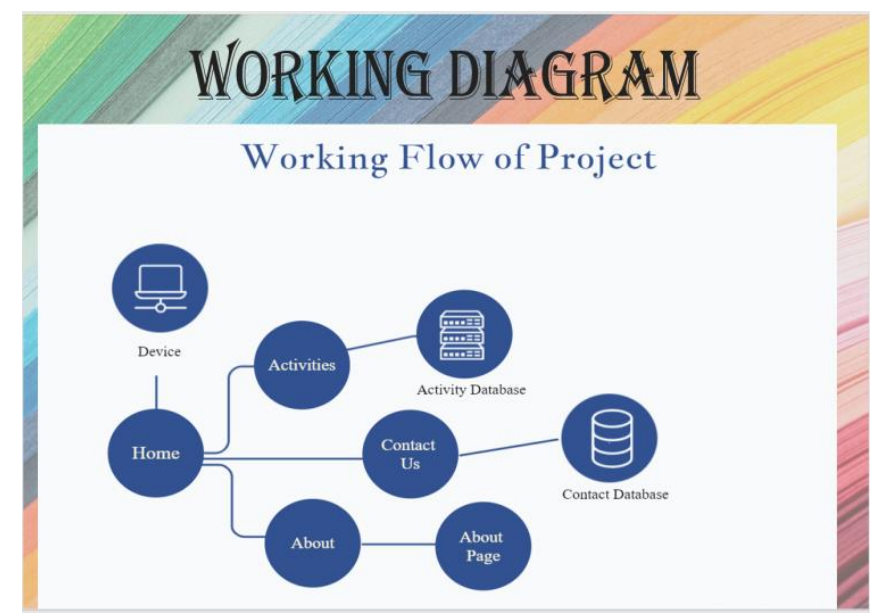

Working Prototype of Project on School Activities using Intelligence Applications after Covid-19

\section{PROBLEM STATEMENT}

In School, There is no such activities which will enhance the knowledge of child with Covid precautions. If parents want to develop their child's knowledge in technology and also for online activities, So there is not such platform where they can do all this without misusing the technology in unawareness.

It is difficult to find any school which is excellent in extra curricular activities and also take care about Covid, for example: hand sanitizer pump, School sanitization. If parents wants to polish their interest, so that, they can think to make a career in it. So, how can they analyse that whatever the school will be able to do it or not, without visiting each school due to Covid 19.

\section{PROPOSED SOLUTION}

The activities that will enhance the child's knowledge will be hand picked to do in action. If parents want to develop their child's knowledge in technology and also for online activities. We will provide a platform where they can only learn and write something without any restriction of parent.

It will not be difficult to find school which is excellent in extra curricular activities when we host it and also will show the caution in website whether we did the precautions for Covid or not, for example: hand sanitizer pump, School sanitization.

If parents wants to polish their interest, so that, their child can make a career in it. So, can visit the website of school also can see that whether the school is able to do it or not, without visiting each school due to Covid 19. (Note : we will mention the facilities, activities, skills and international activities, events in the website.)

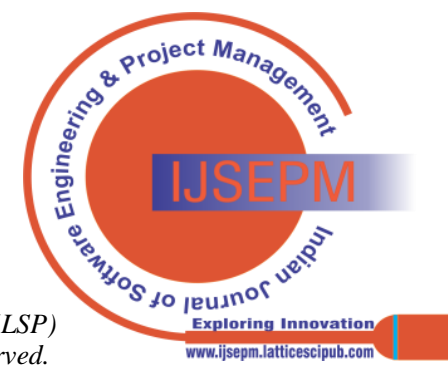




\section{IMPACT OF PROJECT}

$\checkmark$ The output of this project is that, every student have strong immune system in Covid situations, they can make career from their interest in Incredible School Activity. $\checkmark$ School will have own interface/platform for online activities for students so that they could not misuse the technology.

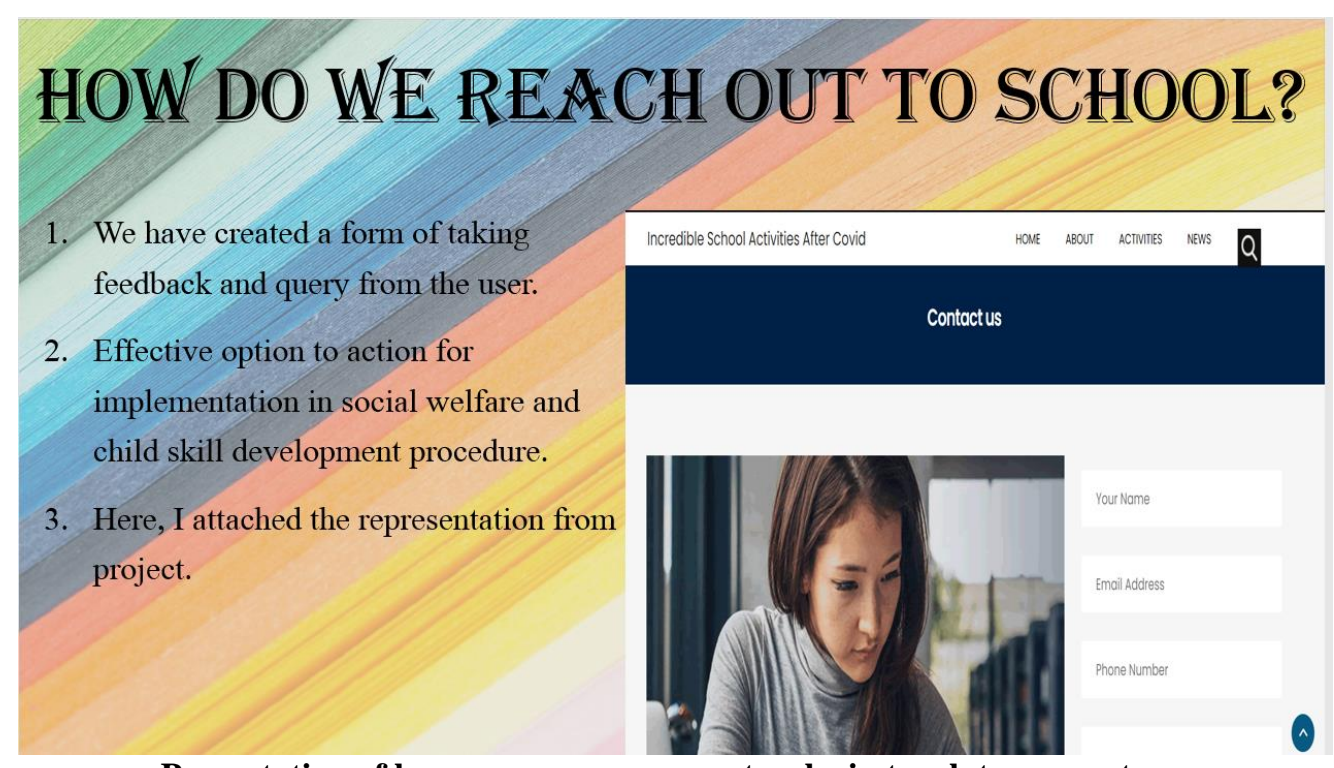

Presentation of how anyone can connect or be in touch to our system.

$\checkmark \quad$ These activities can makes children's Immune System Strong which is a important requirement during and after COVID impact

$\checkmark \quad$ There is some online activities (Activities From Home) in Incredible school that can be done while making some social - distance because of Covid.

$\checkmark$ As this project is all about the incredible school activities after Covid, So the website of this is can be reach out by anyone in just $0.18 \mathrm{sec}$ after hosting it.

\section{IMPACT IN COMMUNITY}

The youth of the community will not understand the knowledge on industry level due to lack of academic knowledge. If student go to college for gaining some industrial knowledge, they can think in a more practical way. Academic is a life time investment we can use in any difficult situation. But as of now situation, due to Covid, everyone are getting passed without knowledge, they can effect their mental approach to think in difficult situation, this will block the logic of thinking for finding solution in worst situation. There are some points we can look into:

1. Academic success is important because it is strongly linked to the positive outcomes we value.

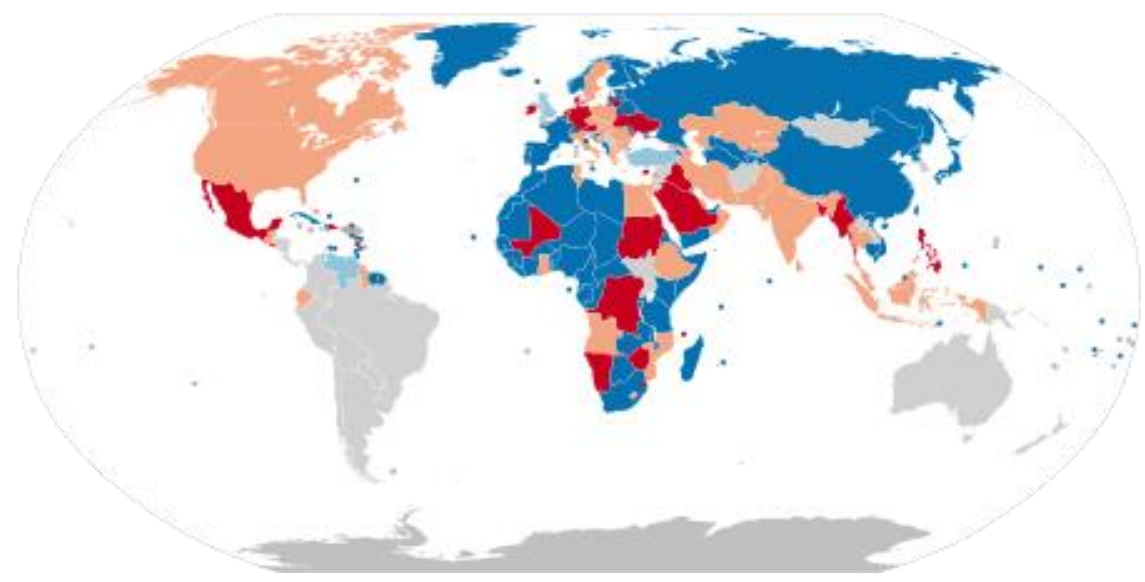

Learners affected by school closures caused by COVID-19 as of February 2021
Full school closures
Partial school closures
Academic break
Online learning
No school closures
No data

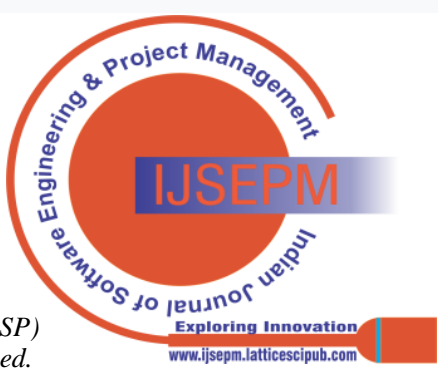


2. Help to differentiate good between two negative and best between two positive.

3. Helps to understand new things in a challenging life.

4. Mind goes in a wide area to think about pros and cons of the situation.

5. Ability to convey our view to other one, etc.

\section{HOW CAN THIS PROJECT IMPACT ON COMMUNITY?}

$\checkmark$ We build the interface to resolve this academic problem. This will help student to acknowledge and learn all the academic content from activities.

$\checkmark$ We will cover all the syllabus, tests, mock ups, etc. just to enhance knowledge of the child like it can be reading and learning from book.

$\checkmark \quad$ These activities can makes children's Immune System Strong which is a important requirement during and after COVID impact $\checkmark \quad$ No one will face the problem of lack of resources to read and learn from it.

$\checkmark \quad$ We will able the option to learn by doing and learn by listening so that if anyone is blind or physically disturbed, they can also learn.

\section{SOME SERIOUS POINT}

There are some facts to look into for awareness of academic knowledge and school activity

$\Upsilon 4$ March 2020: UNESCO released the first global numbers on school closures and affected students on 3 March. It reported that 22 countries on three continents had enacted preventive measures including the temporary closure of schools and universities, impacting 290.5 million students around the world.

\section{Country-wide school closures by country/territory}

\begin{tabular}{|c|c|c|c|}
\hline $\begin{array}{l}\text { Countries } \\
\text { and } \\
\text { territories }\end{array}$ & $\begin{array}{l}\text { Number of learners } \\
\text { enrolled from pre- } \\
\text { primary to upper- } \\
\text { secondary education }\end{array}$ & $\begin{array}{c}\text { Number of learners } \\
\text { enrolled in tertiary } \\
\text { education } \\
\text { programmes }\end{array}$ & Additional information \\
\hline India & $286,376,216$ & $34,337,594$ & $\begin{array}{l}\text { On } 16 \text { March 2020, India declared a } \\
\text { countrywide lock-down of schools and } \\
\text { colleges. On } 19 \text { March, the University } \\
\text { Grants Commission asked universities to } \\
\text { postpone exams until } 31 \text { March. The board } \\
\text { exams conducted } \\
\text { by CBSE and ICSE boards were } \\
\text { postponed until } 31 \text { March at first and then } \\
\text { later until July. Online learning was } \\
\text { encouraged. By April } 2021 \text { almost all } \\
\text { States had opened schools. }\end{array}$ \\
\hline
\end{tabular}

\ 5 March 2020: The majority of learners affected by COVID-19 emergency measures were located in China, with 233 million learners affected, followed by Japan at 16.5 million and Iran at 14.5 million.

$\Upsilon 19$ March 2020: A total of $50 \%$ of the students worldwide were affected by school closures, corresponding to nationwide closures in 102 countries and local closures in 11 countries affecting 1 billion people.

\ 27 March 2020: Nearly 90 per cent of the world's student population was out of class.

$\Upsilon$ As of 12 January 2021, approximately 825 million learners are currently affected due to school closures in response to the pandemic. According to UNICEF monitoring, 23 countries are currently implementing nationwide closures and 40 are implementing local closures, impacting about 47

percent of the world's student population. 112 countries' schools are currently open.

\section{RESULT}

This project can increase efficiency of skill development and career opportunities from their interest in respective activity. Effective feedback option to action for implementation for contributing in social welfare and child skill development procedure.

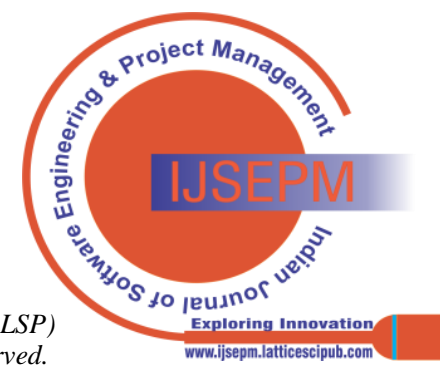


Managing the impact of COVID-19 on education systems without losing required knowledge for students via Incredible school activity as well. Every child can be Identified by their skills in school activities to all over the world and can inspire others and motivate themself as well.

\section{CONCLUSION}

This will open the door to learn something extra apart from college and school studies from activities and resources collected from all over the world. This website will help students to connect with learning without going to school or college. The main aim of the project to reach out to those who want learn something by doing it, by practicing it in a way you like to learn from activities.

\section{REFERENCE}

1. https://en.wikipedia.org/wiki/Impact_of_the_COVID19_pandemic_on_education

2. https://www.unicef.org/press-releases/schools-more-168-millionchildren-globally-have-been-completely-closed

3. https://www.washingtonpost.com/education/2020/03/04/schoolclosures-because-coronavirus-affect-290-million-students-aroundworld-unesco-says/

\section{AUTHORS PROFILE}

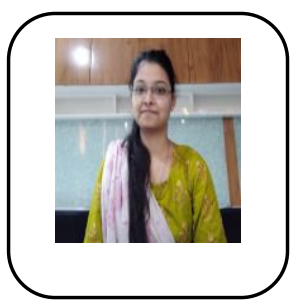

Ruchi Sahu, is correctly in final year of Master of Computer Application. She made a website as her Major project in MCA which is selected for a National Convection (Final Scrutiny) of AICTE CHATRA VISHWAKARMA AWARD 2020. She is also selected for Girl Script Summer of Code 2021 an Open Source Program conduct in all over the world and ranked in Top - 100 performers among the all participants from the world. She is also contributed for Google Summer of Code issue. Attended the National Conference on Advances in Information Science and Technology 2021

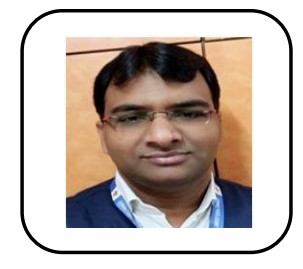

Dr. Jay Kumar Jain, is currently working as an Associate Professor \& Head in Department of Computer Applications, Sagar Institute of Research \& Technology, Bhopal. He did his Ph. D. from Maulana Azad National Institute of Technology Bhopal in 2015. He was awarded with Research Fellowship by MHRD for completing his Ph.D. He has research as well as teaching experience of about 14 years. He has published around 45+ research papers and book chapters in SCI/SCOPUS/Referred International/National Journal and Conferences. He has also published 2 patents and registered 2 copyrights in IPR, India. He has been a reviewer in many international journals/conferences including Elsevier, IEEE Access, and Springer. He has lifetime membership of various professional societies such as CSI, Franklin, IDES, IAENG, SDIWC, and many more. He has also working as an innovation Coordinator in Institution's Innovation Council (IIC), SIRT Bhopal, under Ministry of Education (MoE), Govt. of India. His research interests include Wireless Sensor Networks, Internet of Things, and Mobile Ad hoc Networks. 